УДК 336.14

Галазюк Н.М. к.е.н., доцент

Galaziuk N. Candidate of Economic Sciences, Associate Professor https://orcid.org/0000-0001-7918-4268

Зелінська О.М., к.е.н., доцент

Zelinska O., Candidate of Economic Sciences, Associate Professor https://orcid.org/0000-0001-9103-6460

\title{
ПРІОРИТЕТНІ НАПРЯМИ ЕФЕКТИВНОСТІ СПІВПРАЦІ УКРАЇНИ 3 МІЖНАРОДНИМИ КРЕДИТНИМИ ІНСТИТУТАМИ
}

\author{
Луцьккий націіональний технічний університет
}

Визначено основні пріоритетні напрями розширення співробітництва України з міжнародними кредитними інститутами, доведено необхідність дослідження даної проблематики. Виходячи 3 актуальності запропонованої тематики, стаття присвячена обгрунтуванню пріоритетних напрямів розширення та ефективної співпраці України з міжнародними кредитними інститутами.

Обгрунтовано доцільність залучення кредитних ресурсів для України. Найбільший результат країна отримала від перших кредитів, що надійшли від МВФ та Міжнародного банку розвитку та реформування. Дані кредитні ресурси призначені для формування золотовалютних резервів та фінансовокредитної системи країни.

В статті досліджено кредитну діяльність провідних міжнародних кредитних інституцій, окреслено ключові програми та стратегічні напрями партнерства міжнародних кредитних організацій з Україною. Визначено пріоритетні напрями сприяння співпраці, що дали б змогу підвищити ефективність залучених коштів і створити сприятливий інвестиційний клімат у країні. Окреслено найбільш проблемні моменти співпраці України з світовими кредитними інститутами.

Обгрунтовано необхідність розбудови механізму управління з метою підвищення ефективності співпраці України з міжнародними кредитними інституціями як важливого інструменту політики держави 3 метою здійснення економічних реформ, і як наслідок можливість вчасно адаптуватися до сучасних змін в міжнародній економіці.

Визначено, що вдосконалення співробітництва України із міжнародними кредитними організаціями забезпечить нашій країні позитивні результати в період реалізації економічних реформ, підсилить роль України у формуванні міжнародних валютно-фінансових відносин; зростання довіри та інтересу іноземних інвесторів до вітчизняної економіки, і як наслідок ріст обсягів іноземного інвестування; можливість використання послуг міжнародних організацій, що забезпечить вирішення нагальних завдань державної політики в Україні.

Ключові слова: міжнародні кредитні інститути, кредитні ресурси, державна політика, Міжнародний валютний фонд, Світовий банк.

\section{PRIORITY AREAS FOR EFFICIENCY OF COOPERATION BETWEEN UKRAINE AND INTERNATIONAL CREDIT INSTITUTIONS}

\author{
Lutsk National Technical University
}

The main priority areas for expanding Ukraine's cooperation with international credit institutions have been identified, and the need to study this issue has been proved. Based on the relevance of the proposed topic, the article is devoted to justifying the priority areas of expansion and effective cooperation of Ukraine with international credit institutions.

The expediency of attracting credit resources for Ukraine is substantiated. The country received the greatest results from the first loans received from the IMF and the International Development and Reform Bank. These credit resources are intended for the formation of gold and foreign exchange reserves and the financial and credit system of the country.

The article examines the lending activities of leading international credit institutions, outlines the key programs and strategic areas of partnership of international credit organizations with Ukraine. Priority areas for promoting cooperation have been identified, which would increase the efficiency of borrowed funds and create a favorable investment climate in the country. The most problematic moments of Ukraine's cooperation with world credit institutions are outlined. 
The necessity of building a management mechanism to increase the effectiveness of Ukraine's cooperation with international credit institutions as an important tool of state policy to implement economic reforms, and as a consequence the ability to adapt to modern changes in the international economy.

It is determined that the improvement of Ukraine's cooperation with international credit organizations will provide our country with positive results during the implementation of economic reforms, strengthen Ukraine's role in the formation of international monetary and financial relations; the growth of confidence and interest of foreign investors in the domestic economy, and as a consequence, the growth of foreign investment; the possibility of using the services of international organizations, which will ensure the solution of urgent problems of public policy in Ukraine.

Key words: international credit institutions, credit resources, public policy, the International Monetary Fund, the World Bank.

Постановка проблеми у загальному вигляді i ïi зв'язок 3 важливими науковими та практичними завданнями. Глобалізаційні процеси у сучасній світовій економіці створюють сприятливі умови для зміцнення міждержавних фінансових відносин. Важливим залишається обгрунтування напрямів розширення співробітництва 3 міжнародними кредитними інститутами, що в свою чергу пов'язано із необхідністю підвищення рівня результативності використання залучених коштів та соціальноекономічного розвитку країни.

Необхідність досліджень з питань розширення співпраці України з міжнародними кредитними організаціями зумовлена тим, що інтеграція у світову економічну систему сьогодні розглядається як ключовий фактор трансформації вітчизняної економіки, який потребує розробки нових, раціональних напрямів державної політики в суспільному розвитку.

Сьогодні існує гостра потреба у фінансових ресурсах для здійснення економічних реформ та вирішення нагальних соціальних проблем в Україні. Тому як і усі суб'єкти світової економіки наша держава активно налагоджує співпраці із міжнародними кредитними інститутами, що в свою чергу збільшить об'єми зовнішньої заборгованості та посилить кредитну залежність України. Проте, слід відмітити, що на сьогоднішній день, більша частина країн світу залучає кредитні ресурси за для того аби вирішувати свої внутрішні, як економічні, так і соціальні проблеми. Тому, актуальним постає завдання не так до обсягів міжнародних кредитів, як до їх ефективного використання та ефективного управління обсягами зовнішньої заборгованості.

Аналіз останніх досліджень, у яких започатковано вирішення проблеми. Дослідження теоретичних та розробка практичних аспектів співпраці України 3 впливовими міжнародними кредитними інституціями знайшла свій відбиток у працях як відомих економістів-теоретиків, так і досвідчених експертів-практиків, серед яких Білорус О.Г., Боринець С.Я., Вахненко Т.К, Гальчинський А.С., Скриль В.В., Дзеркаль А.Б., Колосова В.П., Рибальченко К.О. та інші. Проте, не зважаючи на значну кількість наукових праць фахівців у цій сфері питання, розширення та ефективності співпраці України з міжнародними кредитними інститутами перебувають в центрі уваги урядовців, політиків та науковців $є$ актуальним та потребує подальших досліджень.

Цілі статті. Метою написання статті висвітлення основних пріоритетних напрямків ефективної співпраці України з міжнародними кредитними інститутами.

Виклад основного матеріалу дослідження 3 повним обгрунтуванням отриманих наукових результатів. На сьогоднішній день, коли економічна ситуація нашої держави є далеко не найкращою у світі, країна катастрофічно втрачає довіру інвесторів дуже важливою є співпраця з міжнародними кредитними інститутами яка призводить до розширення досвіду України, створення необхідної законодавчої бази, забезпечення макроекономічної і фінансової стабільності, розвитку приватного сектора, удосконалення системи соціального захисту населення.

Через конфлікт на Сході країни та нестабільну політичну ситуацію створюються несприятливі умови для економічного розвитку країни, внаслідок чого породжуються 
ризики та економічні проблеми. Найоптимальніший спосіб вирішення такої ситуації - це подальше здійснення економічних реформ та макроекономічне коригування розвитку. На наш погляд, серед основних кроків та пріоритетів мають стати: досягнення макроекономічної стабільності, укріплення банківського сектору, реформування енергетичного сектору, запровадження серйозних та невідкладних заходів щодо подолання корупції, деолігархізація, зміцнення підзвітності, поліпшення інвестиційного клімату, запровадження адресних програм соціального захисту для бідних та вразливих верст населення.

«Незважаючи на перші ознаки стабілізації, перспективи економіки України залежить від того, як розвиватиметься конфлікт на Сході, та від того, чи буде спроможна влада підтримувати та реалізовувати реформи у складних та непевних умовах» [1, с.153]. Для пом'якшення наслідків кризових явищ та нестабільної політичної ситуації, з якими стикнулася наша країна, ключову роль відіграє політична воля та готовність влади здійснювати макроекономічні та структурні реформи.

При визначенні основних пріоритетів використання залучених кредитних ресурсів, слід наголосити на тому, що найбільш результативними стали кредити МВФ та Міжнародного банку розвитку та реформування. Саме завдяки цим кредитам з'явилася можливість сформувати золотовалютні резерви країни та власну фінансово-кредитну систему. Окрім того, ці кредитні ресурси сприяли проведенню ефективної монетарної політики, грошової реформи і як наслідок введення в обіг власної національної грошової одиниці.

У результаті проведеної в Україні системної діагностики країни за методикою Світового банку було виявлено три основні причини, які стоять на заваді до сталого відновлення та досягненню високих результатів що покращення добробуту в країні, а саме: низька продуктивність приватного сектору, макроекономічна нестабільність та неефективність надання послуг. А також, бізнес-інтереси у владі, поширена корупція впливають на прийняття державних рішень та заважають розв'язанню проблем у сфері макроекономіки, продуктивності та надання послуг. Вплив бізнес-інтересів сформував економіку та дав можливість окремим особам одержувати за рахунок держави вигоду від приватизації, концесій, субсидій на енергію, державних закупівель, пільгових кредитів, державних боргових гарантій, перепадів цін та ухиляння від сплати податків. Вплив бізнес-інтересів стримував економічне зростання України незважаючи на те, що країна має кваліфікований людський капітал, вигідне місце розташування та багата на природні ресурси.

На вирішення вищезазначених проблем схвалений у квітні 2017 року Середньостроковий план пріоритетних дій Уряду, «що визначає п’ять пріоритетних напрямів, а саме:

- економічне зростання: на основі збільшення обсягів експорту та інвестицій, реалізації податкової та митної реформ, дерегуляції, земельної реформи, приватизації, реформування енергетики та підтримання макроекономічної стабільності шляхом продовження фіскальної консолідації;

ефективне врядування: передбачає проведення реформи державного управління, децентралізації і реформи державних фінансів;

- розвиток людського капіталу шляхом проведення реформи системи охорони здоров'я, освіти, поліпшення надання державної соціальної підтримки, розвитку культури і спорту;

- верховенство права і боротьба з корупцією шляхом підтримки ефективного функціонування інститутів боротьби з корупцією, забезпечення рівного доступу до правосуддя та ефективного захисту прав власності;

- безпека та оборона передбачає захист суверенітету та територіальної цілісності держави, а також найважливіші аспекти безпеки громадян» [2]. 
Світовим банком ухвалено Концепцію партнерства з Україною на 2017-2021 роки яка цілком узгоджується з заявленими Урядом пріоритетами. Мета Концепції Світового банку на 2017-2021 фінансові роки полягає в підвищенні ефективності бізнес-діяльності та відновленню вітчизняної економіки. 3 огляду на це основними напрямами Концепції партнерства $€$ :

по-перше, протидія корупції, краще урядування та робота з населенням;

- по-друге, забезпечення функціонування ринків;

- по-третє, фінансова та фіскальна стійкість, ефективне та результативне надання послуг (Рис.1.).

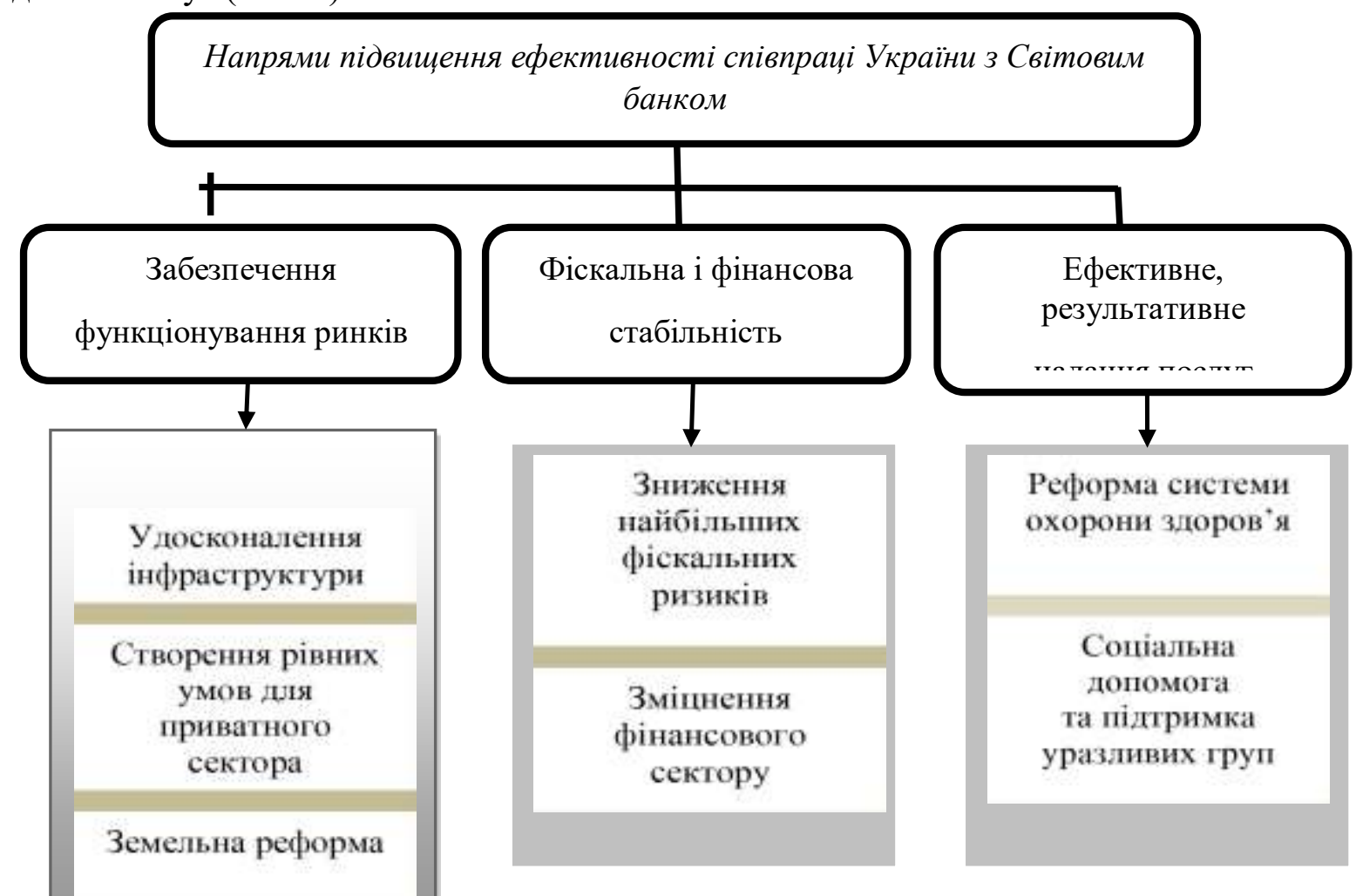

Рис. 1. Заходи сприяння підвищення результативності співпраці України 3 Групою Світового банку

Виклики, що стоять перед Україною у сфері урядування, належать до найбільших перешкод на шляху до поліпшення перспектив зростання ефективності бізнес-діяльності та вивільнення потенціалу приватного сектору.

Успішність та ефективність діяльності міжнародних кредитних інститутів в Україні значною мірою залежить від системних реформ у ключових галузях, включаючи енергетику, інфраструктуру, фінансові ринки, ринки капіталу, а також від поступу у здійсненні приватизації. Поліпшення умов для ведення бізнес-діяльності та зниження рівня корупції залишаються ключовими пріоритетами в реформуванні, проте повільний поступ у здійсненні відповідних заходів призводить до зменшення обсягу нових інвестицій із боку міжнародних кредитних інститутів.

Проблеми, які виникають у взаєминах України з міжнародними кредитними інституціями, насамперед пов'язані як зі специфікою кредитних інституцій, так i політичною та економічною ситуацією України. Найбільші проблемні моменти співпраці України з світовими кредитними інститутами наведено на рис. 2. 


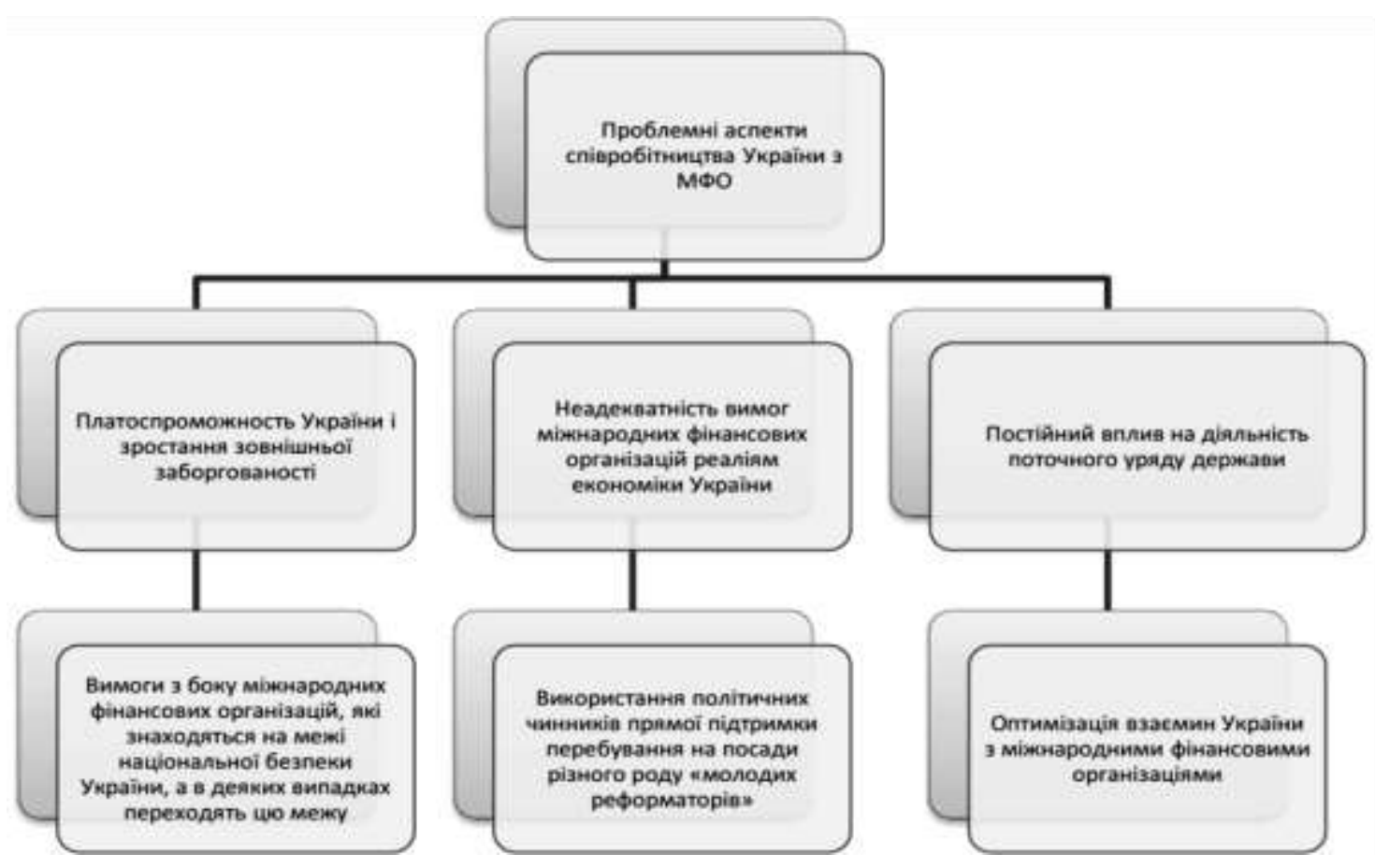

Рис.2. Проблемні аспекти співробітництва України з світовими кредитними інститутами

Взаємини України з міжнародними кредитними інституціями мають на меті визначення «оптимальних параметрів взаємовідносин, які $б$ не допускали як конфронтаційну поведінку, так і втрату своєї економічної та політичної безпеки. Визначення необхідних параметрів і цілей відносин із зовнішніми кредиторами $\epsilon$ важливою передумовою оптимізації безпосередньо зовнішньої заборгованості та підвищення ефективності бізнес-діяльності в Україні. Адже фактично йдеться про два важливих фінансових фактори: про обслуговування залучених раніше зовнішніх запозичень і про перспективи отримання нових надходжень 3 інших країн. Причому щодо другого фактора така оптимізація має відношення до широкого спектру цілей отримання нових фінансових надходжень з-за кордону - як від міжнародних кредитних установ, так і від власників приватного капіталу» [3].

Якщо, говорити про напрями використання кредитів МВФ Україною, то необхідно зауважити, що «значна частина цих коштів пішла на надання кредитів Міністерству фінансів України і була використана для обслуговування зовнішнього боргу, фінансування дефіцитів платіжного та торговельного балансів, у тому числі закупівель по імпорту для багатьох сфер діяльності, включаючи паливно-енергетичний комплекс, сільське господарство та ін. Необхідно також відмітити, що надані Уряду кредити мають неінфляційний характер. Враховуючи вплив інфляції на скорочення ВВП, неважко оцінити, що кредити МВФ, які були надані в скрутний час, вигідні Україні: без них розміри економічної кризи та ії наслідки були б для нашої країни значно гіршими» [4].

Формування довгострокових відносин України з таким кредитором, як МВФ, потребує виконання зобов'язань щодо орієнтирів і здійснення заходів економічної політики за широким колом питань. Меморандум про співпрацю між МВФ та Україною необхідно розглядати з одного боку, як прагнення та можливості нашої держати здійснювати зміни соціально-економічного характеру, що підтримуються авторитетними світовими експертами, а з іншого готовність міжнародних кредитних інститутів надавати позики. 
Проведення в Україні економічних реформ сприятиме в подальшому співробітництву з МВФ та іншими міжнародними кредитними інститутами без залучення від них коштів, а зокрема шляхом консультативної підтримки та технічної допомоги.

«Співпраця 3 групою Світового банку повинна розглядатися в якості стратегічного напряму практичного здійснення програми соціально-економічних реформ та залучення зовнішнього фінансування для розвитку інфраструктури. У зв'язку з цим Кабінету Міністрів України було б доцільним розглядати «Стратегію Партнерства 3 Україною» (розроблену Світовим банком) як форму та механізм соціальноекономічного прогнозування та планування на середньострокову перспективу» [4].

Принципи захисту державних інтересів України у відносинах з міжнародними кредитними інститутами повинні спиратися на пріоритети довгострокових цілей соціального, політичного та економічного розвитку.

Досвід ряду країн, які здійснили ринкову трансформацію, і самої України свідчить, що міжнародні кредити можуть активно сприяти вирішенню фінансових та інших проблем. Ефективність співпраці 3 міжнародними кредитними структурами вирішальним чином залежить від відповіді на питання:

- по-перше, співвідношення вигоди від збільшення показників відкритості та лібералізації національної економіки із можливими втратами національних товаровиробників і споживачів;

- по-друге, яким чином узгоджуються інтереси національної економіки 3 урахуванням різноманітних комбінацій використання внутрішніх і зовнішніх ресурсів.

В цьому випадку велике значення мають також політичні чинники співпраці України з міжнародними кредитними інститутами.

Повноцінне запровадження фінансового механізму оцінки ефективності бізнесдіяльності в контексті використання міжнародних фінансових ресурсів та формування системи показників результативності використання зовнішніх кредитів, отримання результатів їх використання створить умови для збільшення обсягів інвестицій в економіку держави.

Розробка середньострокових планів, орієнтованих на результат: оптимізує процес управління бюджетними ресурсами на всіх етапах - від постановки мети й розробки планів до їхньої реалізації; забезпечить взаємозв'язок між розпорядниками й споживачами бюджетних ресурсів; дозволить визначити пріоритетні напрямки витрат бюджетних коштів; надасть реальні можливості для здійснення якісного фінансового контролю шляхом переходу від оцінки правомірності витрат коштів бюджету й відповідності фактичних і планових витрат до оцінки ступеня реалізації програм, на які заплановані державні видатки.

Узагальнення умов та досвіду співробітництва різних держав 3 міжнародними кредитними інституціями дозволяє сформулювати наступні актуальні для України напрямки щодо «підвищення ефективності співпраці нашої держави 3 цими установами:

- консультативна допомога міжнародних кредитних інституцій не повинна суперечити стратегічним інтересам реформування української економіки та ії інтеграції у світове господарство. Це означає, що параметри макроекономічної стабілізації, не повинні бути самодостатніми та відриватися від найголовнішого завдання - досягнення ринкової рівноваги, реструктуризації та економічного зростання;

- співробітництво України з міжнародними кредитними інститутами вимагає перегляду умов надання кредитів у частині розмежування економічних та політичних критеріїв;

- винятково важливим для України є заручення підтримкою країн-лідерів світового господарства, які відіграють ключову роль у міжнародних кредитних організаціях, а саме США, країни Європейського Союзу, Японія через активізацію 
консультативного і переговорного процесу з ними. Особливої ваги набуває відхід нашої держави від політики багатовекторності в побудові взаємовідносин зі світовим господарством, визначеність України щодо зовнішньоекономічних та зовнішньополітичних пріоритетів, значно знижуючи ефективність реалізації стратегічної мети інтеграції в Свропейський Союз;

- 3 метою пом'якшення зовнішнього боргового тиску та підвищення ефективності іноземних кредитних ресурсів необхідно поступово диверсифіковувати їхні джерела на користь тих, які не супроводжуються жорсткими інституціональними умовами. Це може бути подальше розширення співробітництва з такими регіональними структурами кредитного сприяння як Європейський банк реконструкції та розвитку, Азіатський банк розвитку, Банк ЧЕС та інші» [5, с.125].

Розбудова механізмів управління 3 метою підвищення ефективності бізнесдіяльності в контексті співпраці України з міжнародними кредитними інституціями $€$ важливим напрямом політики держави $з$ метою здійснення економічних реформ, і як наслідок можливість вчасно адаптуватися до сучасних змін в міжнародній економіці.

Висновки. У організаційно-методичному плані вдосконалення співробітництва України із міжнародними кредитними організаціями має на меті забезпечення позитивних результатів від проведення економічних реформ шляхом посилення ролі України в становленні міжнародних валютно-фінансових відносин; використання ряду заходів, які використовуються у практиці міжнародних кредитних інститутів і зможуть вирішити актуальні завдання вітчизняної економічної політики; зростання довіри іноземного інвестора до української політики, як наслідок ріст обсягів іноземного інвестування; можливість використання послуг міжнародних організацій, що забезпечить вирішення нагальних завдань державної політики в Україні. Досягнення зазначених вище орієнтирів створить сприятливі передумови для сталого економічного зростання вітчизняної економіки та підвищення добробуту населення в країні.

\section{Список бібліографічного опису}

1. Кульбіда М.В. Перспективи співробітництва України із Світовим банком. Стратегії розвитку України. 2015. №2. С. 149-154.

2.Середньостроковий план пріоритетних дій Уряду до 2020 року та плани пріоритетних дій Уряду. URL: https://www.kmu.gov.ua/ua/

3. Скриль В.В., Дзеркаль А.Б. Проблемні аспекти співробітництва міжнародних фінансових організацій 3 Україною. URL: file://C:/Users/Intel/Downloads/ecfor_2016_2_16.pdf

4. "Щодо вдосконалення роботи України 3 МВФ - МБР". Аналітична записка. URL: https://niss.gov.ua/doslidzhennya/ekonomika/schodo-vdoskonalennya-roboti-ukraini-z-mvf-mbrr-analitichna-zapiska

5. Інституційне забезпечення бізнес-діяльності в умовах світової інтернаціоналізації сфер виробництва та послуг [Текст] : монографія / Баула О.В., Галазюк Н.М., Зелінська О.М., Лютак О.М., Савош Л.В. - Луцьк : Вежа-Друк, 2019. -284 с.

\section{References}

1. Kul'bida M.V. Perspektyvy spivrobitnytstva Ukrayiny iz Svitovym bankom. Stratehiyi rozvytku Ukrayiny. 2015. \#2. S. 149154. [in Ukrainian].

2. Seredn'ostrokovyy plan priorytetnykh diy Uryadu do 2020 roku ta plany priorytetnykh diy Uryadu. URL: https://www.kmu.gov.ua/ua/. [in Ukrainian].

3. Skryl' V.V., Dzerkal' A.B. Problemni aspekty spivrobitnytstva mizhnarodnykh finansovykh orhanizatsiy z Ukrayinoyu. URL: file:///C:/Users/Intel/Downloads/ecfor_2016_2_16.pdf. [in Ukrainian].

4. "Shchodo vdoskonalennya roboty Ukrayiny z MVF - MBRR". Analitychna zapyska. URL: https://niss.gov.ua/doslidzhennya/ekonomika/schodo-vdoskonalennya-roboti-ukraini-z-mvf-mbrr-analitichna-zapiska. [in Ukrainian].

5. Instytutsiyne zabezpechennya biznes-diyal'nosti v umovakh svitovoyi internatsionalizatsiyi sfer vyrobnytstva ta posluh Tekst : monohrafiya / Baula O.V., Halazyuk N.M., Zelins'ka O.M., Lyutak O.M., Savosh L.V. - Luts'k : Vezha-Druk, 2019. -284 s. [in Ukrainian].

Дата подання публікації 21.09.2020 p. 